\title{
Real wage growth in the U.S. health workforce and the narrowing of the gender pay gap
}

Janis Barry ${ }^{*}$ D

\begin{abstract}
Background: Healthcare has been identified as a job engine during recent recessions in the U.S. Whether the healthcare sector provides better than average pay remains a question. This study investigates if wages grew with the expanding demand for healthcare workers between 2001 and 2017. Wage growth in the (1) physicians and surgeons, (2) nurse, (3) healthcare practitioner and technical, (4) healthcare support, and (5) direct patient care jobs are examined. The gender pay gap in each occupation is investigated.

Methods: The American Community Survey (ACS) public use microdata sample (PUMS) for 2001, 2004, 2008, 2013, and 2017 were used to derive hourly wages for full-time, full-year workers aged 18-75. The cumulative percent change in unadjusted, median hourly wages between 2001 and 2017 was calculated for each occupation. Quantile regression estimates predicted a median hourly wage for men and women by year and job after adjusting for differences in demographics, industry, and hours worked.
\end{abstract}

Results: Unadjusted median wage growth was $9.92 \%$ for nurses, $5.68 \%$ for healthcare practitioners, and 37.6\% for physicians between 2001 and 2017. These rates are roughly above the estimated national rate of wage growth at the 50th wage percentile. In healthcare support and direct patient care occupations, workers experienced either stagnant or negative wage growth. Women had lower occupational wages than men.

Conclusion: The slow or negative median wage growth in all but the physician occupation between 2004-2008 and 2008-2013 confirms that healthcare wages in the U.S. are not recession-proof, unlike healthcare employment. Generally, women's earnings grew at rates that were higher or less negative than rates for men. This trend contributed to narrowing the gender pay gap in every occupation except for nurse.

Keywords: Recessions and healthcare workers, Gender pay gaps, Healthcare labor markets

\section{Introduction}

Healthcare has been identified as a job engine during recent recessions in the U.S. This sector is characterized as recession-resistant and capable of generating "good jobs", especially for women with low and middle-skill sets. Whether the healthcare sector provides better than

*Correspondence: barryfiguero@fordham.edu

Department of Economics, Fordham University, 113 West 60th Street, New York, NY 10023, USA average pay remains a question. Women in healthcare were paid less than men with comparable skills who work in the manufacturing and construction sectors [1]. Many entry-level jobs do not provide a career path, with lowerwaged jobs now representing the more substantial proportion of all healthcare employment [2-4].

This study investigates whether wages grew along with the expanding demand for healthcare workers between 2001 and 2017. Real or inflation-adjusted wage growth rates in the (1) physicians and surgeons, (2) nurse, (3) healthcare practitioner and technical, (4) healthcare 
support, and (5) direct patient care occupations are examined. Workers in these occupations directly interact with patients in delivering healthcare services.

The time frame includes events such as the moderate 2001 recession after the World Trade Center bombing, the rise in unemployment due to the Great Recession beginning in 2007 and continuing into 2010, and the economic recovery years of 2013-2017, during which the Affordable Care Act (ACA) was implemented. Three questions are addressed. First, what were the occupationspecific, real median wage trends for full-time, full-year healthcare workers before, during, and after the Great Recession? Secondly, within occupations, what were the major wage determinants? Thirdly, in which occupations did the gender pay gap narrow after adjusting wages for differences in demographics, industry, and hours worked?

\section{Background}

In 2017, healthcare employment as a percent of total U.S. employment was $11 \%$. The number of full-time, yearround workers increased from 5 to 9 million between 2000 and 2017, and most workers were women [5]. In the U.S. and much of the world, occupational clustering by gender is a distinctive feature of health care employment [6].

Healthcare added jobs during the U.S. recession in 2001 and the financial crisis dated December 2007 to June 2009. Oceania and Canada also recorded increased healthcare employment during the Great Recession. Yet, healthcare employment in Europe fell during this time [7]. Austerity measures during the economic crisis caused many European countries to cut salaries and fees for doctors and nurses [8]. However, in the U.S., the average healthcare wage between 2001 and 2014 increased, but remained lower than the national average [9].

The scale of private sector funding and provision of healthcare services gives U.S. employers significant leverage in determining wage rates across healthcare industries. Alternatively, many European countries have national, centralized wage-setting procedures that develop from collective bargaining agreements with trade unions that significantly impact pay in public hospitals and other settings [8]. Therefore, comparing healthcare wages in the U.S. with those found in other OECD countries is difficult, although, during recessionary periods, employment conditions across countries exhibit similarities [7].

In the U.S., the Great Recession encouraged economic restructuring and a reorganization of healthcare industries. As the economy recovered, many workers were moved from higher-paying, often unionized hospital jobs to work in lower-waged ambulatory and long-term care facilities [10, 11]. Hospital consolidation increased employer bargaining power and contributed to slower wage growth for nurses and pharmacists [12]. In 2010, the ACA was passed, and the expansion of health insurance and a rapidly growing older population effectively increased healthcare service demand [2].

Dramatic employment growth in the healthcare sector is associated with rising labor costs. Economists alarmed with increasing healthcare expenditures caution that physicians are overpaid [13]. Some suggest that healthcare employment should be rolled back, layoffs enacted, and remaining jobs given to those who would work them at lower cost [14]. Earnings for physicians and nurses are indeed higher than for comparable workers in the nonhealthcare sector of the economy $[15,16]$. Yet, even if the government were to lower its payments to the highest earners in the health system (e.g., physicians and surgeons), the effect on national healthcare spending would be minimal [17]. Correspondingly, reducing nurses' earnings would also have a limited impact.

\section{Professionalism and gender in healthcare}

The division of labor in healthcare reinforces professional boundaries with occupational closure strategies that can limit the earnings of those with only vocational qualifications [10, 15]. Cross-nationally, occupational hierarchies distinguish jobs requiring significant educational training, credentials, and licensing (high status) from those having fewer employment preconditions (low-status) $[18,19]$. Higher wages for professionals reflect the derived demand for healthcare services and the greater bargaining power and status associated with their occupation. While increased requirements can raise salaries for highly experienced registered nurses, such credentials do little for improving the pay of certified nursing assistants [11]. During 2005-2015, wage inequality increased between professional and non-professional workers in healthcare [10]. And certifications and other closure strategies did not benefit women's wages as they had for men [1].

Disparities in earnings among men and women employed in the same healthcare occupations are not unique to the U.S. Between 2006 and 2014, across lower and upper-middle-income countries, the gender wage gap in healthcare increased while remaining relatively constant in higher-income countries [6]. Gender and health system hierarchies are embedded with institutional practices attached to social characteristics such as race, ethnicity, class, or caste. Fair and accurate professional productivity evaluations are hidden in compensation policies, allowing bias to determine standards and who meets them [19]. 
Cross-national explanations for the gender wage gap in healthcare include women's concentration in specific jobs, specialty choices in medicine, labor market discrimination, the devaluation of caring skills in pay structures, and depressed bargaining power among women [20-23]. Care work by female nurses is often regarded as less valuable than the medical interventions performed by predominantly male physicians [24]. Furthermore, immigrant women and women of color overwhelmingly inhabit the lower-waged care jobs in the U.S. and lack regulatory protections or union representation $[1,3,25]$. Consequently, in the highest-skilled physician and nurse occupations and non-professional healthcare support jobs, pay gaps by gender, race, and nativity are evident $[3$, $10,20,21]$.

\section{Data and statistical analyses}

The American Community Survey (ACS) public use microdata sample (PUMS) for 2001, 2004, 2008, 2013, and 2017 were used to derive hourly wages. Five years of ACS sample data were concatenated, and five datasets were created for each occupational group. The ACS is the largest, individual-level data set capable of tracking healthcare occupations in the U.S. [26]. Conducted annually by the U.S. Census Bureau, it reaches roughly 295,000 U.S. addresses per month. Households are required by law to respond, and response rates are generally about 95\%. The 2001 and 2004 ACS had approximately 1.1 to 1.2 million observations per year. By 2017, this increased to nearly 3.5 million individuals. ACS statistics uniquely provide estimates of consistently defined demographic and economic variables.

Occupations were identified using the Census Bureau's 2010 ACS classification scheme [26]. This scheme organizes homogeneous occupations into clusters. Examples of jobs found within each category and their relevant Census code follow physician and surgeon (3060: (hospitalists, urologists)); nurse (3000-3540: (registered nurse, nurse practitioners); other healthcare practitioner and technical (3000-3540: (chiropractors, dentists)), and healthcare support (3600 -3650: (orderlies, dental assistants)). A fifth category was compiled to include jobs not coded as healthcare occupations in the ACS [27]. This cluster is not homogeneous. The first six jobs demand specific qualifications, while the remaining two have minimal educational or licensing requirements. Direct patient care jobs include medical/health services managers (0350), social/community service managers (0420), psychologists (1820), social workers (2010), counselors (2000), various community and social services specialists (2020), medical/dental/ophthalmic laboratory technicians (8760) and personal/home care aides (4610).
A median hourly wage was determined for all fulltime (30 or more hours a week), full-year (51 weeks) workers aged $18-75$, or for physicians and surgeons, subset to aged 35 years and older. The ACS wage value was divided by usual hours and weeks worked. Median wage growth rates by occupation were calculated. Then, using a quantile regression model, the natural logarithm of the CPI-adjusted, trimmed hourly wage was adjusted for demographic, industry, and hours worked differences. Results from the 50th percentile of the hourly wage distribution are reported.

Independent variables included in the regression analyses were gender (female/male), age (18-34, 35-40, 41-49, 50-59, 60-75), race/ethnicity (non-Hispanic Black/African-American, Hispanic/Latino, non-Hispanic White, Asians/others), nativity (native-born, naturalized citizen, non-citizen), education (high school or lower, some college, Bachelor's degree or higher), and hours of work (30-34, 35-40, 41-50, 51 or more). Four healthcare industries, including hospitals, ambulatory care (physicians' offices, outpatient care centers), and long-term care (home healthcare, nursing care facilities), were included. The fourth industry consists of "other" locations where healthcare employees reported they worked. Largely comprising the government and education sectors, it also included community/social service organizations and retail pharmacies. The listed variables do not capture everything that could affect median hourly wages, so the state of residence and fixed-year effects were included to control for observed and unobserved influences.

The multivariable regression analyses predicted the log median hourly wage for each occupation using weighted, pooled cross-sections of the ACS so that results are nationally representative. Quantile regression modeling was performed using the $\mathrm{R}$ computer language. Robust standard errors for the estimated intercept and coefficients were made using the Huber Sandwich estimator [28].

\section{Descriptive statistics}

Additional file 1: Table S1 provides the pooled-sample characteristics by year for the sample used in the wage regression analyses. For each of the explanatory variables, percentages by gender are also reported. The data confirms the health workforce has grown, and occupational shares have changed over time. Healthcare support's share declined between 2001 (19\%) and 2017 (16.8\%). Nurses increased their share between 2013 (20.7\%) and 2017 (21.6\%) after relative flatness between 2001 and 2013. Direct patient care generally trended upward, reaching $28.9 \%$ of the health workforce in 2017 . Healthcare practitioners experienced a decrease in share from 
2001 to 2013, followed by a substantial increase from $27.5 \%$ to $28.9 \%$ between 2013 and 2017. The proportion of physicians and surgeons generally trended downward, constituting $5.5 \%$ of the total workforce in 2001 but only $5.2 \%$ by 2017 .

Healthcare support and physicians were the only two occupations that lost workforce share between 2001 and 2017. Declines in the physician share are attributed to retirements, whereas low pay and high turnover in healthcare support increase the difficulty of recruitment to this occupation $[3,29]$. All other occupational shares expanded due to rapid growth in healthcare demand [5, $9,16]$.

Women were $74.1 \%$ of the workforce in 2001 , and this increased to $76.5 \%$ by 2017 . Their representation rose in direct patient care, healthcare practitioners, and physicians between 2001 and 2017. The percentage of nonHispanic Whites working in healthcare declined, as did the number of native-born workers. Latinos and Asians, along with naturalized citizens, grew their workforce share, while Black workers saw their employment share decline after 2008, only to rebound by 2017 .

Workers aged 50-59 and 60 years or older increased their share between 2001 and 2017, as did workers aged 18-34. The percentage of workers with higher education credentials increased significantly. Women exhibited higher levels of educational attainment by 2017 . The proportion of the health workforce located in the four healthcare industries was relatively stable. However, women saw job declines in hospitals, while their share of employment in ambulatory and the "other" categories grew between 2001 and 2017. The percentage of female workers reporting working 35 to 40 or 41 to 50 hours a week increased between 2001 and 2017. Among all workers, the percentage working 51 hours or more declined.

\section{Median wage results}

Table 1 reveals that wage growth rates in all occupations were highest between 2001 and 2004. From 2004 to 2008, healthcare support, direct patient care, and healthcare practitioner workers experienced negative wage growth. Nurses and physicians also registered slower wage growth, with physicians having a rate of $1.3 \%$ compared to their $2.47 \%$ rate for 2001-2004. By 2008-2013 healthcare support workers continued to have negative wage growth, and nurses saw real wage declines. Direct patient care and healthcare practitioners experienced less than 1\% annualized wage growth between 2008 and 2013, while physicians realized an improved rate of $2.16 \%$. Between 2013 and 2017, workers in direct patient care and healthcare practitioner jobs suffered wage declines during this period of economic recovery. Healthcare support and nurses had growth of less than $1 \%$. In contrast, physicians saw wages grow at $2.45 \%$.

Overall, between 2001 and 2017, professional workers registered the fastest cumulative median wage growth. Specifically, physicians' wages grew almost four times faster than nurses' (37.6\% versus 9.92\%) and over six times faster than the rate of $5.68 \%$ in healthcare practitioner occupations. Paraprofessional workers in healthcare support had a cumulative wage growth rate of less than one percent. In contrast, the mixed professional direct patient care category experienced a negative wage growth rate of $-8.4 \%$.

\section{Regression-adjusted median wage results}

Table 2 reports the conditional quantile regression coefficients taken at the 0.50 percentile of the wage distribution. The gender dummy coefficients in Table 2 are estimates of the occupational wage penalty for women in 2001, after adjustments for the other covariates. Being a woman decreased the median wage in 2001 (the reference year) by approximately $\left.\left(\mathrm{e}^{-.1452}\right)-1 \times 100\right) 16 \%$ in healthcare support, by $4 \%$ in Nursing, $13 \%$ in direct

Table 1 Median wages by year, occupation with annualized percentage change in real wages

\begin{tabular}{|c|c|c|c|c|c|c|c|c|c|c|}
\hline \multirow[t]{2}{*}{ Occupation } & \multirow[t]{2}{*}{2001} & $\begin{array}{l}\text { Annualized } \\
2001-2004\end{array}$ & \multirow[t]{2}{*}{2004} & \multirow{2}{*}{$\begin{array}{l}\text { Annualized } \\
2004-2008 \\
\% \triangle \text { wage }\end{array}$} & \multirow[t]{2}{*}{2008} & \multirow{2}{*}{$\begin{array}{l}\text { Annualized } \\
2008-2013 \\
\% \triangle \text { wage }\end{array}$} & \multirow[t]{2}{*}{2013} & \multirow{2}{*}{$\begin{array}{l}\text { Annualized } \\
2013-2017 \\
\% \triangle \text { wage }\end{array}$} & \multirow[t]{2}{*}{2017} & \multirow{2}{*}{$\begin{array}{l}\text { Cumulative } \\
2001-2017 \\
\% \triangle \text { wage }\end{array}$} \\
\hline & & $\% \triangle$ wage & & & & & & & & \\
\hline Healthcare support & $\$ 13.61$ & 1.02 & $\$ 14.03$ & -0.18 & $\$ 13.93$ & -0.72 & $\$ 13.43$ & 0.56 & $\$ 13.73$ & 0.88 \\
\hline Nurses & $\$ 29.73$ & 2.41 & $\$ 31.88$ & 0.45 & $\$ 32.45$ & -0.26 & $\$ 32.03$ & 0.51 & $\$ 32.68$ & 9.92 \\
\hline Direct patient care & $\$ 21.77$ & 0.81 & $\$ 22.30$ & -2 & $\$ 20.51$ & 0.16 & $\$ 20.67$ & -0.88 & $\$ 19.94$ & -8.4 \\
\hline Healthcare practitioners & $\$ 22.68$ & 2.48 & $\$ 24.37$ & -0.67 & $\$ 23.72$ & 0.59 & $\$ 24.42$ & -0.47 & $\$ 23.97$ & 5.68 \\
\hline Physicians/surgeons & $\$ 59.36$ & 2.47 & $\$ 63.77$ & 1.32 & $\$ 67.14$ & 2.16 & $\$ 74.40$ & 2.45 & $\$ 81.70$ & 37.6 \\
\hline
\end{tabular}

Sample is full-time/full-year workers, aged 18-75, except physicians and surgeons are $\geq 35$ years of age

Source: American Community Survey, 2001, 2004, 2008, 2013, 2017 
Table 2 Quantile regression estimated coefficients

\begin{tabular}{|c|c|c|c|c|c|}
\hline & $\begin{array}{l}\text { Healthcare support } \\
\text { occupations }\end{array}$ & Nurses & $\begin{array}{l}\text { Direct patient care } \\
\text { occupations }\end{array}$ & $\begin{array}{l}\text { Healthcare practitioner } \\
\text { and technical } \\
\text { occupations }\end{array}$ & $\begin{array}{l}\text { Physicians and } \\
\text { surgeons ( } 35 \text { and } \\
\text { older) }\end{array}$ \\
\hline Intercept & $2.9095(0.0330)^{* * *}$ & $3.5219(0.0153)^{* * *}$ & $3.6710(0.0201)^{* * *}$ & $3.5866(0.0192)^{* * *}$ & $4.3472(0.0287)^{* * *}$ \\
\hline \multicolumn{6}{|l|}{ Sex } \\
\hline Female & $-0.1452(.0278)^{* * *}$ & $-0.0436(0.0118)^{* * *}$ & $-0.1369(0.0111)^{* * *}$ & $-0.1664(0.0141)^{* * *}$ & $-0.2555(0.0318)^{* * *}$ \\
\hline \multicolumn{6}{|l|}{ Age } \\
\hline 18 to 34 & $-0.1708(0.0064)^{* * *}$ & $-0.2602(0.0043)^{* * *}$ & $-0.2644(0.0064)^{* * *}$ & $-0.2465(0.0063)^{* * *}$ & N/A \\
\hline 35 to 40 & $-0.0282(0.0071)^{* * *}$ & $-0.1027(0.0048)^{* * *}$ & $-0.0467(0.0070)^{* * *}$ & $-0.0429(0.0069)^{* * *}$ & $-0.0087(0.0111)$ \\
\hline 41 to 49 & $0.0014(0.0068)$ & $-0.0517(0.0043)^{* * *}$ & $0.0081(0.0067)$ & $-0.0094(0.0064)$ & $0.0460(0.0085)^{* * *}$ \\
\hline 50 to 59 & $0.0127(0.0066)$ & $-0.0226(0.0041) * * *$ & $0.0308(0.0066)^{* * *}$ & $-0.0012(0.0064)$ & $0.0423(0.0089)^{* * *}$ \\
\hline \multicolumn{6}{|l|}{ Race/ethnicity } \\
\hline $\begin{array}{l}\text { Black or African-Amer- } \\
\text { ican }\end{array}$ & $-0.0014(0.0046)$ & $-0.0223(0.0053)^{* * *}$ & $-0.0900(0.0049)^{* * *}$ & $-0.0855(0.0058)^{* * *}$ & $-0.1189(0.0159)^{* * *}$ \\
\hline Hispanic or Latino & $-0.0691(0.0057)^{* * *}$ & $-0.0437(0.0064)^{* * *}$ & $-0.0634(0.0059)^{* * *}$ & $-0.0872(0.0074)^{* * *}$ & $-0.0826(0.0156)^{* * *}$ \\
\hline Asians/other & $-0.0213(.0080)^{* *}$ & $0.0154(0.0054)^{* *}$ & $-0.0640(0.0078)^{* * *}$ & $-0.0066(0.0081)$ & $0.0079(0.0082)$ \\
\hline \multicolumn{6}{|l|}{ Education } \\
\hline High school or less & $-0.01835(0.0069)^{* * *}$ & $-0.1507(0.0112)^{* * *}$ & $-0.05844(0.0050)^{* * *}$ & $-0.6384(0.0052)^{* * *}$ & $-0.2004(0.0142)^{* * *}$ \\
\hline Some college & $-0.1105(0.0067)^{* * *}$ & $-0.01163(0.0026)^{* * *}$ & $-0.3444(0.0043)^{* * *}$ & $-0.4382(0.0038)^{* * *}$ & $-0.7837(0.0333)^{* * *}$ \\
\hline \multicolumn{6}{|l|}{ Industry } \\
\hline Ambulatory & $0.0287(0.0042)^{* * *}$ & $-0.1221(0.0043)^{* * *}$ & $-0.02414(0.0067)^{* * *}$ & $-0.0775(0.0042)^{* * *}$ & $-0.0466(0.0061)^{* * *}$ \\
\hline Long-term care & $-0.2056(0.0043)^{* * *}$ & $-0.1881(0.0038)^{* * *}$ & $-0.4708(0.0067)^{* * *}$ & $-0.0723(0.0053)^{* * *}$ & $-0.1419(0.0496)^{* *}$ \\
\hline $\begin{array}{l}\text { Other/Govt., Educ., } \\
\text { Community Org. }\end{array}$ & $-0.1648(0.0069)^{* * *}$ & $-0.1795(0.0052)^{* * *}$ & $-0.3485(0.0049)^{* * *}$ & $-0.1209(0.0046)^{* * *}$ & $-0.1499(0.0115)^{* * *}$ \\
\hline \multicolumn{6}{|l|}{ Nativity } \\
\hline Naturalized citizen & $0.0322(0.0064)^{* * *}$ & $0.0426(0.0055)^{* * *}$ & $-0.0445(0.0078)^{* * *}$ & $0.0226(0.0077)^{* *}$ & $-0.0021(0.0080)$ \\
\hline Non-citizen & $-0.0482(0.0078)^{* * *}$ & $-0.0154(0.0075)^{*}$ & $-0.2094(0.0101)^{* * *}$ & $-0.0870(0.0115)^{* * *}$ & $-0.1277(0.0134)^{* * *}$ \\
\hline \multicolumn{6}{|l|}{ Hours worked } \\
\hline 30 to 34 & $-0.0646(0.0053)^{* * *}$ & $0.0093(0.0046)^{*}$ & $-0.2802(0.0093)^{* * *}$ & $0.0317(0.0065)^{* * *}$ & $0.0022(0.0135)$ \\
\hline 41 to 50 & $-0.00569(0.0056)^{* * *}$ & $-0.0515(0.0033)^{* * *}$ & $0.0096(0.0040)^{*}$ & $-0.0244(0.0046)^{* * *}$ & $-0.0037(0.0050)$ \\
\hline 51 or more & $-0.3525(0.0106)^{* * *}$ & $-0.2615(0.0073)^{* * *}$ & $-0.2525(0.0074)^{* * *}$ & $-0.03243(0.0086)^{* * *}$ & $-0.0871(0.0098)^{* * *}$ \\
\hline \multicolumn{6}{|l|}{ Year } \\
\hline 2004 & $-0.0500(0.0316)$ & $0.0965(0.0190)^{* * *}$ & $0.0073(0.0137)$ & $0.0849(0.0170)^{* * *}$ & $0.0101(0.0188)$ \\
\hline 2008 & $-0.0584(0.0293)^{*}$ & $0.1153(0.0137)^{* * *}$ & $-0.0469(0.0117)^{* * *}$ & $0.0590(0.0146)^{* * *}$ & $0.1582(0.0221)^{* * *}$ \\
\hline 2013 & $-0.0735(0.0285)^{*}$ & $0.0923(0.0136)^{* * *}$ & $-0.0708(0.0121)^{* * *}$ & $0.0470(0.0146)^{* *}$ & $0.2287(0.0187)^{* * *}$ \\
\hline 2017 & $-0.0754(0.0285)^{* *}$ & $0.1109(0.0132)^{* * *}$ & $-0.0633(0.0117)^{* * *}$ & $0.0287(0.0145)^{*}$ & $0.2660(0.0181)^{* * *}$ \\
\hline \multicolumn{6}{|c|}{ Full interaction (gender by year) } \\
\hline 2004 & $0.0657(0.0327)^{*}$ & $-0.0189(0.0198)$ & $0.0113(0.0158)$ & $-0.0415(0.0190)^{*}$ & $0.1901(0.0428)^{* * *}$ \\
\hline 2008 & $0.0488(0.0300)$ & $-0.0255(0.0145)$ & $0.0169(0.0133)$ & $-0.0094(0.0162)$ & $-0.0111(0.0361)$ \\
\hline 2013 & $0.0466(0.0293)$ & $-0.0095(0.0144)$ & $0.0125(0.0137)$ & $0.0003(0.0162)$ & $0.0524(0.0368)$ \\
\hline 2017 & $0.0762(0.0292)^{* *}$ & $-0.0135(0.0139)$ & $0.0240(0.0133)$ & $0.0139(0.0161)$ & $0.0937(0.0348)^{* *}$ \\
\hline State fixed effects & $\checkmark$ & $\checkmark$ & $\checkmark$ & $\checkmark$ & $\checkmark$ \\
\hline Sample size & 78,893 & 87,835 & $1,12,080$ & $1,19,223$ & 22,836 \\
\hline
\end{tabular}

Sample is full-time, full-year workers, aged 18-75, except physician and surgeons are $\geq 35$ years of age Source: American Community Survey 2001, 2004, 2008, 2013, 2017

${ }^{* * *} P \leq 0.001,{ }^{* *} P \leq 0.01,{ }^{*} P \leq 0.05$

Dependent variable is log(hourly wages in real dollars)

patient care, $15 \%$ in healthcare practitioners, and $23 \%$ in the physician surgeon category.
In every occupation except physicians, workers younger than 41 made significantly less than employees aged $60-75$ (the omitted category). Nurses aged 
60-75 years of age earned more than other age groups. Physicians aged 41-59 earned higher median wages than those aged 60-75. African Americans earned less than non-Hispanic Whites (the omitted category) except in healthcare support. Latinos realized wage penalties in every domain. Non-Hispanic Whites made more than Asians/others in healthcare support and direct patient care but earned less in nursing.

Naturalized citizens had higher median wages than native-born workers in healthcare support, healthcare practitioner, and nursing occupations. Non-citizens always earned less than native-born workers. Individuals without a Bachelors' Degree (the omitted category) were paid less than those who had completed college.

Jobs located in hospitals (the omitted industry) paid significantly higher median wages when compared to the other three sectors. Long-term care workers in healthcare support, nursing, and direct patient care had 19\%, $17 \%$, and $38 \%$ lower wages, respectively, than their hospital-based colleagues. Healthcare practitioners and physicians faced their most significant wage penalty in the "other" sector, earning $11 \%$ and $14 \%$ less than their peers in hospitals.
Those working 30-34 hours a week in healthcare support, nurse, and healthcare practitioner jobs had significantly lower wages than workers in the omitted 35-40 hours category. Laboring 41-50 hours a week lowered wages in the healthcare support, nurse, and healthcare practitioner jobs. And wage penalties were evident for working 51 or more hours across occupations.

Year dummy variable coefficients estimated the difference between the year intercept and the 2001 omitted intercept and accounted for potential changes in wages over time. Table 2 reveals that when compared to 2001, there was a negative wage trend beginning in 2008 for direct patient care and healthcare support laborers. The gender-year interaction term calculated the difference between the effect of gender on median wages in a specific year compared to its impact in 2001. In 2004, women's earnings in healthcare support and physicians increased, while their wages fell in the healthcare practitioner occupation. But the significant 2004 gender interaction coefficient for physicians is suspect as $72.8 \%$ of male and $52.9 \%$ of female physicians had top-coded earnings that year. Thus, the median wage for all physicians was understated, but the underestimation was more significant for male physicians. In 2017, women in

Table 3 Regression-adjusted predicted real median hourly wage by occupation, gender and year

\begin{tabular}{|c|c|c|c|c|c|c|c|c|c|c|}
\hline & \multirow[t]{3}{*}{2001} & \multicolumn{2}{|l|}{ Annualized } & \multicolumn{2}{|l|}{ Annualized } & \multicolumn{2}{|l|}{ Annualized } & \multicolumn{2}{|l|}{ Annualized } & \multirow{3}{*}{$\begin{array}{l}\text { Cumulative } \\
2001-2017 \\
\% \triangle \text { wages }\end{array}$} \\
\hline & & 2001-2004 & 2004 & 2004-2008 & 2008 & 2008-2013 & 2013 & 2013-2017 & 2017 & \\
\hline & & \multicolumn{2}{|l|}{$\% \triangle$ wages } & \multicolumn{2}{|l|}{$\% \triangle$ wages } & \multicolumn{2}{|l|}{$\% \triangle$ wages } & \multicolumn{2}{|l|}{$\% \triangle$ wages } & \\
\hline \multicolumn{11}{|c|}{ Healthcare support occupations } \\
\hline Female & $\$ 13.54$ & 0.51 & $\$ 13.75$ & -0.62 & $\$ 13.41$ & -0.35 & $\$ 13.18$ & -0.69 & $\$ 13.55$ & 0.07 \\
\hline Male & $\$ 15.65$ & -1.67 & $\$ 14.88$ & -0.19 & $\$ 14.77$ & -0.3 & $\$ 14.55$ & -0.05 & $\$ 14.52$ & -7.22 \\
\hline F/M wage & $86.50 \%$ & & $92.40 \%$ & & $90.70 \%$ & & $90.50 \%$ & & $93.30 \%$ & \\
\hline \multicolumn{11}{|c|}{ Nurse occupations } \\
\hline Female & $\$ 29.61$ & 2.62 & $\$ 32.00$ & 0.3 & $\$ 32.39$ & -0.14 & $\$ 32.17$ & 0.36 & $\$ 32.64$ & 10.23 \\
\hline Male & $\$ 30.93$ & 3.29 & $\$ 34.08$ & 0.47 & $\$ 34.72$ & -0.46 & $\$ 33.93$ & 0.48 & $\$ 34.58$ & 11.8 \\
\hline F/M wage & $95.70 \%$ & & $93.80 \%$ & & $93.20 \%$ & & $94.80 \%$ & & $94.30 \%$ & \\
\hline \multicolumn{11}{|c|}{ Direct patient care occupations } \\
\hline Female & $\$ 21.03$ & 0.63 & $\$ 21.43$ & -1.21 & $\$ 20.41$ & -0.56 & $\$ 19.84$ & 0.48 & $\$ 20.22$ & -3.85 \\
\hline Male & $\$ 24.12$ & 0.23 & $\$ 24.29$ & -1.34 & $\$ 23.01$ & -0.47 & $\$ 22.47$ & 0.19 & $\$ 22.64$ & -6.13 \\
\hline F/M wage & $87.10 \%$ & & $88.20 \%$ & & $88.70 \%$ & & $88.20 \%$ & & $89.30 \%$ & \\
\hline \multicolumn{11}{|c|}{ Healthcare practitioner and technical occupations } \\
\hline Female & $\$ 21.68$ & 1.45 & $\$ 22.64$ & 0.15 & $\$ 22.78$ & -0.04 & $\$ 22.73$ & -0.12 & $\$ 22.62$ & 4.33 \\
\hline Male & $\$ 25.60$ & 2.88 & $\$ 27.88$ & -0.65 & $\$ 27.15$ & -0.24 & $\$ 26.83$ & -0.47 & $\$ 26.33$ & 2.85 \\
\hline F/M wage & $84.60 \%$ & & $81.20 \%$ & & $83.90 \%$ & & $84.70 \%$ & & $85.90 \%$ & \\
\hline \multicolumn{11}{|c|}{ Physician and surgeon occupations } \\
\hline Female & $\$ 56.10$ & 6.9 & $\$ 68.53$ & -1.32 & $\$ 64.99$ & 2.71 & $\$ 74.30$ & 1.99 & $\$ 80.38$ & 43.2 \\
\hline Male & $\$ 72.43$ & 0.33 & $\$ 73.14$ & 3.78 & $\$ 84.84$ & 1.43 & $\$ 91.06$ & 0.92 & $\$ 94.45$ & 30.4 \\
\hline F/M wage & $77.40 \%$ & & $93.60 \%$ & & $76.60 \%$ & & $81.60 \%$ & & $85.10 \%$ & \\
\hline
\end{tabular}

Sample is full-time/full-year workers, aged 18-75, except physicians and surgeons are $\geq 35$ years of age

Source: American Community Survey 2001, 2004, 2008, 2013, 2017 
healthcare support and physicians' made wage gains of $7 \%$ and $10 \%$.

\section{Gender wage gaps by year and occupation}

Table 3 provides the predicted median wages for men and women by year and occupation. The log regression coefficients from Table 2 were used to predict wages, and an adjusted gender wage gap was calculated. The wage gap narrowed between 2001 and 2017 in every occupation except for nurse. As a percentage of men's, women's median wages in nursing declined from $95.7 \%$ in 2001 to $94.3 \%$ in 2017 but still reflected the greater pay parity found in this job. The gender wage gap in the physician occupation appears drastically cut between 2001 and 2004, with women losing ground between 2004 and 2008. However, these findings are likely an artifact of top coding [see Additional file 2].

In the healthcare support and direct patient care occupations, both men and women were negatively impacted by the great recession, as evidenced in the annualized percentage wage change columns for 2004-2008 and 2008-2013. Additionally, male median wages grew more slowly than women's during 2008-2013 in the nurse, healthcare practitioner, and physician professions. During the recovery years of 2013-2017, both men and women in nurse, direct patient care, and physician jobs realized improved wage growth. Alternatively, all healthcare support and healthcare practitioner employees experienced negative wage growth.

Overall, men in healthcare support registered a negative cumulative wage change, while women experienced wage stagnation. As a group, direct patient care workers experienced cumulative negative wage growth. Women in the healthcare practitioner and physician occupations had higher overall wage growth rates than men, except in nursing.

\section{Discussion}

This study contributes to the international literature documenting the adverse impacts of economic recessions on healthcare workers and existing occupational gender pay disparities $[6,7]$. Even as healthcare employment increased between 2001 and 2017, median wage growth was uneven across occupations. Not every occupation was equally disadvantaged by the Great Recessionary shock. Between 2013 and 2017, when wages would be expected to rise as the economic recovery proceeded, only the professional occupations exhibited wage growth for both genders. Gould [30] estimated cumulative, unadjusted, real wage growth at the 50 th percentile as $5 \%$ for all workers aged 18-64, both full and part-time, between 2000 and 2017. This study's cumulative rates of unadjusted median wage growth were $9.92 \%$ for nurses, $5.68 \%$ for healthcare practitioners, and $37.6 \%$ for physicians (Table 1). These rates are above those reported nationally for the 50th wage percentile, confirming that professionals do better $[10,15,18]$.

Wage growth at the 50th percentile of the wage distribution is bifurcated. The less than $1 \%$ cumulative growth rate in healthcare support means that these workers earned far less than the 2017 estimated living wage (\$16.07) necessary for meeting a family's basic needs [31]. Earnings were limited for men and less-educated workers. Those with only a high school education had wages $17 \%$ lower than their college-educated peers.

Consistent with other studies, industry location was a significant determinant of wages, and hospital workers earned more [10, 12]. Between 2001 and 2017, jobs in healthcare support moved to lower-paying sectors. In data not shown but available from the author, by 2017, $47 \%$ of healthcare support jobs were in the lower-paying, long-term care, and "other" sectors. There was also an uptick in healthcare support located in ambulatory care [29].

The estimated negative wage growth for direct patient care employees is surprising given the number of skilled and credentialed workers in this category. One explanation lies in the increased percentage of these jobs $(56 \%$ in 2017) located in the "other" sector. Higher-paid workers such as psychologists and health services managers face a wage "ceiling effect" in the public sector [22]. Were these jobs located in the private sector, they would pay more. Additionally, approximately one-third of the direct patient care category was composed of home/personal care aides in 2017 (data not shown). These jobs are the lowest-paid and least regulated in healthcare [11,32].

Estimated gender pay gaps for the nurse and physician occupations are comparable to other studies, despite different countries, data sets, and control variables [33-37]. Reductions in the role of observables, such as education and experience, are causing the gender pay gap in professional occupations to close [38]. Since longer work hours were negatively associated with wages, this variable would explain little of the gender wage gap using a decomposition model [38, 39]. By 2017 a higher percentage of women than men worked between 35 and 40 hours a week (Additional file 1: Table S1). More women working these hours means increased earnings across occupations. Collective bargaining coverage for healthcare workers, especially in the public sector, could have reduced wage inequality among men and women over time [40]. Whether the limited labor market mobility of non-White and immigrant men in healthcare support contributed to their wage growth decline requires more investigation $[3,25]$. 
Despite noticeable gains, gender pay disparities in nursing and medicine signal the limitations placed on women's decision-making, promotion, and training opportunities [24, 35, 37]. The substantial pay gap between male and female primary care physicians has been associated with women's additional time spent with patients. More extended face-to-face interactions mean fewer office visits and lower employer revenues, resulting in pay reductions for female physicians [41]. Compensation schemes that discount the value of care services force women to choose between commitment or bargaining for pay [42].

Nurses want respect and collaboration from doctors, the ability to practice at the top of their license, sound referral systems, and adequate resources [24]. But the market has historically devalued skills demanding empathy, dedication, and intrinsic motivation, which form a large part of gendered care service provision [22, 42]. This contributes to the unequal pay between men and women for comparable work in nursing, medicine, and the allied professions.

\section{Conclusion}

Wages are pro-cyclical. The slow or negative median wage growth in all but the physician occupation between 2004-2008 and 2008-2013 confirms that U.S. healthcare wages are not recession-proof, unlike healthcare employment. Workers in the three professional occupations had cumulative rates of wage growth between 2001 and 2017 that were higher than the national rate, confirming these are indeed "good jobs". Alternatively, wages in both healthcare support and direct patient care exhibited growth rates below the national median.

Women were consistently paid less than men, despite controls for occupation, industry, and human capital. Yet, the gender pay gap narrowed in all professions except nurse. Gender-neutral job evaluation schemes and legal actions for enforcing equal pay must continue to challenge gender pay disparities, especially at the top of the wage distribution where the gap is most significant [33, 38]. Hikes in the federal governments' reimbursement rates and insurance subsidies raise healthcare workers' income. Increasing the federal minimum wage to $\$ 15$ or more would overwhelmingly benefit the lowest-paid women and further close the gender pay gap [4].

\section{Supplementary Information}

The online version contains supplementary material available at https://doi. org/10.1186/s12960-021-00647-3.

Additional file 1: Table S1. Summary Statistics (2001-2017). Percentage of full-time, full-year workers, aged 18-75, by year, regression variable and gender.
Additional file 2: Percent of physicians and surgeons-with top-coded income values. By year and gender. Top-coded physician and surgeon income 2001, 2004, 2010, 2013, 2017.

\section{Acknowledgements}

I would like to acknowledge the dedicated assistance of Richard Griffiths of mGTI Statistics in completing this study.

\section{Authors' contributions}

Sole author. The author read and approved the final manuscript.

\section{Funding}

Not applicable.

\section{Availability of data and materials}

The datasets generated during and/or analyzed during the current study are available from the corresponding author on reasonable request.

\section{Declarations}

\section{Ethics approval and consent to participate}

This research is a secondary analysis based on public records. Fordham Institutional Review Board determined the research does not involve human subjects on June 4, 2021.

\section{Consent for publication \\ Not applicable.}

\section{Competing interests}

The author declares no competing interests.

Received: 10 June 2021 Accepted: 18 August 2021

Published online: 28 August 2021

References

1. Dill J, Hodges MJ. Is healthcare the new manufacturing? industry, gender, and "good jobs" for low-and middle-skill workers. Soc Sci Res. 2019;84:102350.

2. Frogner BK, Spetz J, Parente ST, Oberlin S. The demand for health care workers post ACA. Int J Health Econ Manag. 2015;15(1):139-51.

3. Hill N, McGregory R, Peoples J. Noncitizen employment and the wages of healthcare support workers in the U.S. J Labor Res. 2018;39:433-61.

4. Himmelstein K, Venkataramani AS. Economic vulnerability among U.S. female health care workers: potential impact of a \$15-per-hour minimum wage. Am J Public Health. 2019;2:198-205.

5. Day J, Christnacht C. Your Healthcare is in Women's Hands. U.S. Census Bureau; 2019. https://www.census.gov/library/stories/2019/08/yourhealth-care-in-womens-hands.html.

6. Shannon G, Minckas N, Tan D, et al. Feminisation of the health workforce and wage conditions of health professions: an exploratory analysis. Hum Resour Health. 2019;17(72):2535-49. https://doi.org/10.1186/ s12960-019-0406-0.

7. Russo G, Silva TJ, Gassasse Z, Filippon J, Rotulo A, Kondilis E. The impact of economic recessions on health workers: a systematic review and best-fit framework synthesis of the evidence from the last 50 years. Health Policy Plan. 2021;36(4):542-51. https://doi.org/10.1093/heapol/czaa180.

8. Buchan J, Kumar A, Schoenstein M. Wage-setting in the hospital sector, OECD Health Working Paper No. 77. 2014. https://doi.org/10.1787/5jxx5 6b8hahl-en.

9. Dolfman $M$, Insco M, Holden RJ. Healthcare jobs and the great recession. Mon Labor Rev. 2018. https://doi.org/10.21916/mlr.2018.17.

10. Applebaum E, Batt R. Organizational restructuring in U.S. healthcare systems: implications for jobs, wages, and inequality. 2017. CEPR. https:// cepr.net/images/stories/reports/organizational-restructuring-healthcare2017-09.pdf. 
11. Osterman P. Improving job quality in long-term care. In P. Osterman, ed. Creating good jobs: an industry-based strategy. Cambridge: MIT Press; 2019. p. 115-144.

12. Prager E, Schmitt M. Employer consolidation and wages: evidence from hospitals. Am Econ Rev. 2021;111(2):397-427.

13. Case A, Deaton A. Deaths of despair and the future of capitalism. Princeton: Princeton University Press; 2020. p. 191-211.

14. Skinner J, Chandra A. Health care employment growth and the future of U.S. cost containment. JAMA. 2018;319(18):1861-2. https://doi.org/10. 1001/jama.2018.2078.

15. Glied S, Ma S, Pearlstein I. Understanding pay differentials among health professionals, non-professionals, and their counterparts in other sectors. Health Aff. 2015;34:6. https://doi.org/10.1377/hlthaff.2014.1367.

16. Dolfman $M$, Insco $M$, Holden R. Nursing and the great recession. Mon Labor Rev. 2017. https://doi.org/10.21916/mlr.2017.18.

17. Gottlieb JD, Polyakova M, Rinz K, Shiplett H, Udalova V. Who values human capitalists' human capital? Healthcare spending and physician earnings. U.S. Census Working paper number CES-20-23; 2020. https:// www.census.gov/library/working-papers/2020/adrm/CES-WP-20-23. html.

18. Lightman N. Discounted labour? Disaggregating care work in comparative perspective. Int Labour Rev. 2017;156:243-67.

19. Hay K, McDougal L, Percival V, Henry S, Klugman J, Wurie H, Geeta RG. Disrupting gender norms in health systems: making the case for change. Lancet. 2019;393(10190):2535-49.

20. Lo Sasso AT, Armstrong D, Forte G, Gerber S. Differences in starting pay for male and female physicians persist; explanations for the gender gap remain elusive. Health Aff. 2020;39(2):256-63.

21. Muench U, Sindelar J, Buysch S, Buerhaus P. Salary differences between male and female registered nurses in the United States. JAMA. 2015:313(12):1265-7.

22. Budig M, Hodges M, England P. Wages of nurturant and reproductive care workers: individual and job characteristics, occupational closure, and wage-equalizing institutions. Soc Probl. 2019;66(2):294-319. https://doi. org/10.1093/socpro/spy007.

23. Müller T. She works hard for the money: tackling low pay in sectors dominated by women-evidence from health and social care. ETUl: Brussels. 2019; Working Paper 2019.11.

24. Karimi-Shahanjarini A, Shakibazadeh E, Rashidian A, Hajimiri K, Glenton C, Noyes J, Lewin S, Laurant M, Colvin CJ. Barriers and facilitators to the implementation of doctor-nurse substitution strategies in primary care: a qualitative evidence synthesis. CDSR. 2019;4:CD010412. https://doi.org/ 10.1002/14651858.CD010412.

25. Hodges M. Intersections on the class escalator: gender, race, and occupational segregation in paid care work. Socio Forum. 2020;35:24-49. https:// doi.org/10.1111/socf.12566.

26. U.S. Census Bureau. American Community Survey. https://www.census. gov/acs/www/methodology/sample-size-and-data-quality/responserates/index.php Accessed 28 May 2021.

27. Patterson DG, Snyder CR, Frogner BK. Immigrants in health care occupations. Seattle, WA: Center for Health Workforce Studies, University of Washington; 2017.
28. Koenker, R. (2018). Quantile regression in R: a vignette. https://cran.r-proje ct.org/web/packages/quantreg/vignettes/rq.pdf. Accessed 28 May 2021.

29. AMN Healthcare. Healthcare jobs in 2017: rising demand overcame policy uncertainty. https://www.amnhealthcare.com/latest-healthcare-news/ healthcare-jobs-in-2017/.

30. Gould E. The state of American wages 2017. Economic Policy Institute; 2018. https://www.epi.org/publication/the-state-of-american-wages2017-wages-have-finally-recovered-from-the-blow-of-the-great-reces sion-but-are-still-growing-too-slowly-and-unequally/\#epi-toc-10.

31. Nadeau CA, Glasmeier A. Bare facts about the living wage in American 2017-2018. https://livingwage.mit.edu/articles/31-bare-facts-about-theliving-wage-in-america-2017-2018.

32. Spetz J, Stone RI, Chapman SA, Bryant N. Home and community-based workforce for patients with serious illness requires support to meet growing needs. Health Aff. 2019;38(6):902-9.

33. Boniol M, Mclsaac M, Xu L, Wuliji T, Diallo K, Campbell J. Gender equity in the health workforce: analysis of 104 countries. Working paper 1. Geneva: World Health Organization; 2019 (WHO/HIS/HWF/Gender/WP1/2019.1).

34. Ly DP, Seabury SA, Anupam JB. Differences in incomes of physicians in the United States by race and sex: an observational study. BMJ. 2016;353: i2923. https://doi.org/10.1136/bmj.i2923.

35. Wilson BL, Butler MJ, Butler RJ, Johnson WG. Nursing gender pay differentials in the new millennium. J Nurs Scholarsh. 2018;50:102-8.

36. Desai T, Ali S, Fang X, Thompson W, Pankaj J, Vachharajani T. Equal work for unequal pay: the gender reimbursement gap for healthcare providers in the United States. PMJ. 2016;92:571-5.

37. Lyons N, Bernardi K, Olavarria O, Shah P, Dhanani N, Loor M, Holihan J, Liang M. Gender disparity among American medicine and surgery physicians: a systematic review. Am J M Sc. 2021;361(2):151-68.

38. Foster T, Murray-Close M, Landivar LC, deWolf M. An evaluation of the gender wage gap using linked survey and administrative data. U.S. Census Bureau. Center for Economic Studies. Paper \#20-34; 2020.

39. Denning J, Jacob B, Lefgren L, vom Lehn C. The return to hours worked within and across occupations: implications for the gender wage gap. NBER Working Paper 25739; 2019. https://doi.org/10.3386/w25739

40. Card D, Lemieux T, Riddell WC. Unions and wage inequality: the roles of gender, skill and public sector employment. CJE. 2020;53:140-73. https:// doi.org/10.1111/caje.12432.

41. Ganguli I, Sheridan B, Gray J, Chernew M, Rosenthal MB, Neprash H. Physician work hours and the gender pay gap-evidence from primary care. N Engl J Med. 2020;383(14):1349-57. https://doi.org/10.1056/NEJMsa2013 804.

42. Folbre N, Gautham L, Smith K. Essential workers and care penalties in the United States. Fem Econ. 2021;27(1-2):173-87.

\section{Publisher's Note}

Springer Nature remains neutral with regard to jurisdictional claims in published maps and institutional affiliations.

Ready to submit your research? Choose BMC and benefit from

- fast, convenient online submission

- thorough peer review by experienced researchers in your field

- rapid publication on acceptance

- support for research data, including large and complex data types

- gold Open Access which fosters wider collaboration and increased citations

- maximum visibility for your research: over 100M website views per year

At BMC, research is always in progress.

Learn more biomedcentral.com/submissions 